Click www.researchjournal.co.in/online/subdetail.html to purchase.

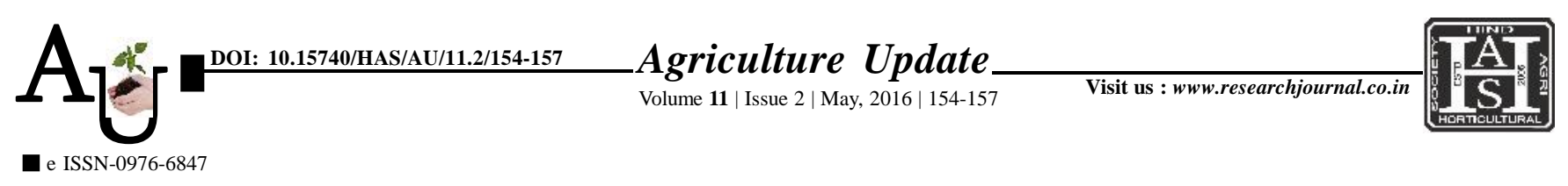

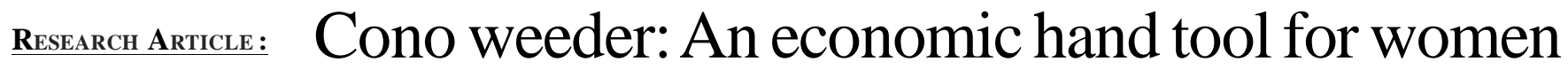 labour in paddy field
}

\author{
N. A. SHIRSAT, S. S. CHAVAN, V. V. AWARE, P. U. SHAHARE, K.G. DHANDE \\ AND SEEMA V. AWARE
}

Article Chronicle:

SUMMARY : Rice (Oryza sativa L.) is one of the most leading food crops in the world within the Received : 02.04.2016;

Revised :

17.03.2016;

Accepted :

18.04 .2016 worldwide-cultivated cereals, and is second only to wheat in terms of annual food consumption. Rice is major crop of Konkan region of Maharashtra. Weeds are the major problem in rice crop. Weeding operation in rice field is very tedious and drudgeries and time consuming operation as it done manually. Hence, to reduce the drudgery and force requirement, it is necessary to develop women friendly cono weeder as per the feedback received from women workers with ergonomic consideration. The actual field capacity for cono weeder (DBSKKV) and cono weeder 1 (Double handled), cono weeder 2 (Single handled) were found to be $0.0094 \mathrm{ha} / \mathrm{h}, 0.0110 \mathrm{ha} / \mathrm{h}$ and $0.0133 \mathrm{ha} / \mathrm{h}$. The field efficiency for cono weeder (DBSKKV) and cono weeder 1 (Double handled), cono weeder 2 (Single handled) were found to be 56.98 per cent, 64.77 per cent and 79.35 per cent, respectively. The weeding efficiency of cono weeder (DBSKKV) and cono weeder 1 (Double handled), cono weeder 2 (Single handled) were found to

KeY Words :

Cono weeder, Paddy, Hand tool be 74.01 per cent, 79.82 per cent and 84.58 per cent, respectively. The cost of cono weeder (DBSKKV) and developed cono weeder 1 (Double handled), cono weeder 2 (Single handled) were Rs. 1150/-, Rs.800/- and Rs.785/-, respectively. The operating cost of cono weeder (DBSKKV) and developed cono weeder 1 (Double handled) and cono weeder 2 (Single handled) were Rs. 24.74/-h, Rs. 24.06/-h, Rs. 24.04/-h, respectively.

How to cite this article : Shirsat, N. A., Chavan, S.S., Aware, V. V., Shahare, P. U., Dhande, K. G. and Aware, Seema V. (2016). Cono weeder: An economic hand tool for women labour in paddy field. Agric. Update, 11(2): 154-157 (DOI : 10.15740/HAS/AU/11.2/154-157).

Author for correspondence :

\section{S.S. CHAVAN}

Department of Farm Machinery and Power, College of Agricultural Engineering and Technology, Dr. Balasaheb Sawant Konkan Krishi Vidyapeeth, Dapoli, RATNAGIRI (M.S.) INDIA

See end of the article for authors' affiliations 